\title{
FEATURES OF THE PROCESS MODEL FOR PENITENTIARY EDUCATION SYSTEM DIVERSIFICATION
}

\author{
${ }^{1}$ Neile Kayumovna Schepkina, \\ ${ }^{2}$ Elyana Yuozovna Lecite, ${ }^{3}$ Elena Anatolyevna Burdukovskaya, \\ ${ }^{4}$ Tatyana Sergeyevna Eremeyeva and ${ }^{5}$ Ludmila Marsovna Alekseyeva \\ ${ }^{1-4}$ Amur State University, Blagoveschensk, Ignatyevskoe Shosse, 21, Amur Region, 675027, Russia \\ ${ }^{5}$ Almetyevsk State Oil Institute, Almetyevsk, Lenin Street, 2, Tatarstan, 423450, Russia
}

Received 2014-04-10; Revised 2014-04-11; Accepted 2014-04-19

\begin{abstract}
The article covers features of the process model for penitentiary education system diversification. Issues of prison inmate education are of contemporary relevance over the past 30 years since criminalexecutive system has undergone a number of changes due to changes and amendments to criminal laws and rules of proceedings, including those affected by international standards, European Prison Rules ensuring the rights of imprisoned persons to education. Russian criminal-executive, court supervision and correctional system adopted to have been implemented till 2020 provides qualitative changes in approaches related to practices of serving sentences and measures to prevent recidivism.Creating a set of incentives for social adaptation of a special group of inmates, while serving their sentences and after it, is the basic category in the range of initiatives that currently have been considered in terms of developing penitentiary system. One of the most significant ones among them is the incentive to take advantage of the educational opportunities available to them in prison.
\end{abstract}

Keywords: Process Model, Penitentiary Education System, Convicted and Sentenced Prisoner, Places of Deprivation of Liberty

\section{INTRODUCTION}

Upgrading education is becoming one of the key tasks in the current stage of the development of the society because it is education that creates basic conditions for training human resources capable of working with innovations (Mukhametzyanova, 2010; Shaydullina, 2009). As it is said in the Concept of the Federal target program of education for 2011-2015, one of the current system challenges is the increase of the role of human resource as a key factor of economic developmen (CFTPE, 2012). It is for this reason that currently the search for education system diversification is being conducted to meets the requirements of global competition in labor market, on the one hand and social needs of people, on the other hand.
Since its early days penitentiary education system in Russia has been closely connected to the search of effective methods of rehabilitation and correction in prisons and reduction of the amount of recidivism criminal act. From the very first steps of Russian penitentiary system development training and education of prisoners and offenders has been considered as a basic means of rehabilitation and correction (Poznyshev, 1923). Prison education and training helped to reveal the relationship of the dynamics of rehabilitation quality and education level. In spite of the changes in the criminal law, the number of prisoners and offenders still remains high. According to the official data from Federal Penitentiary Service of Russia by April, 1, 2012, there were 741.6 of prisoners and offenders serving punishment in this country:

Corresponding Author: Neile Kayumovna Schepkina, Amur State University, Blagoveschensk, Ignatyevskoe Shosse, 21, Amur Region, 675027, Russia Tel/Fax: +7 (4162) 394-620 
- 623,5 thousand prisoners and offenders in 755 convict colonies

- 41.7 thousand in 145 correctional settlements

- And 2.7 Thousand in 46 educational colonies for young offenders (Schepkina, 2013)

The problem of educating prisoners and offenders is of particular interest due to the fact that quite a big number among them haven't finished either secondary or vocational schools. Yet, it is a common knowledge that it is extremely difficult for them to find a highly paid employment to adapt to community settings conditions and requirements (Fitrianto et al., 2014).

Today for persons in their 20-s and younger serving sentences in places of deprivation do not only have the right for general secondary education and vocational training but also are obliged to get it (Aungles, 1994; Bada et al., 2014). In correctional colonies and educational colonies for young offenders in Russia there are 318 night schools and 547 training and consulting centers, 332 vocational and technical schools and their branches, 563 Labor Adaptation Centers.

At the same time, the process of prison education system formation is lagging behind the social needs, does not take into account the full strategic challenges of improving life standards. Besides, there is an apparent gap between the research in the field of general and professional training and learning in common educational institutions of this country and specific education process in closed correctional institutions.

\section{MATERIALS AND METHODS}

Education provides a means to address the negative mental states as well as feelings of convicted caused be their being in isolation from society. It helps to neutralize and eliminate their negative demands and create positive ones, as well as positive attitude and interests. Analyzing the data received related to the age of convicted we noticed that 18-30 year-olds choose education as top priority in life $(43 \%)$. This means that they point out education as vital area, value-oriented and perspective for their future, including their life after release.

Penitentiary education system is a set of general education institutions and vocational education institutions which as a territory are located in penitentiary environment/surrounding and provide educational programs and national educational standards at various levels and styles of lifelong education, the system of education management and subdivisions subordinate to penitentiary system, ensuring functioning of the educational institutions for persons serving a sentence of imprisonment.

To study penitentiary education system, assess its status and develop ways to diversify, it is required to have a set of categories and concepts that allows you to carry out the work. The key concept in the study is "diversification" (in Latin diversify is for change, diversity). Accordingly, it should be clarified what is meant by 'diversification in prison education' and identify its value in the context of development of optional education systems in penitentiary aspect.

Diversification of prison education is looked upon as a qualitatively new socio-pedagogical phenomenon reflecting innovation processes in reforming educational system in correction and rehabilitation institutions on the basis of the principles humanization and democratization of social practice. Diversification can be considered as an objective, as a tool, as a result, as a process (Masalimova, 2013). Except for the last of the above mentioned, all attitudes under consideration have local significance and certain limits for theoretical-and-methodological constructions application. Diversification in educational system should be considered inseparably, in close connection to, educational environment of the correctional institution created on its basis, relevant designed environment, as well as transformations in content and procedure characteristics of educational process with axiology focus.

In the framework of the study diversification of prison education system is defined as the process of changing and improving of all its components, developing and implementing the educational system on its basis. It should be realized as an integrated spatiotemporal educational model in the prison environment and aimed at the development of the potential of the convicted person in arranged valueoriented activities with positive tendency and using the provided learning experience. This phenomenon intrinsically reflects the process of transition from developing its theoretical model to designing a normative model of educational system with humanist orientation/approach and optimization educational and penitentiary resources to meet the educational needs and enhance the potential of a convicted person.

Because of some certain social and educational reasons disadvantages in educational institutions of 
penitentiary education system have been accumulating for rather long period of time, contradictions have been sharpening and have resulted in quality and development rate decrease.

It is our opinion that with introducing and implementing the following perspective ideas it is possible to develop prison education system and to solve the prevailing problems in it:

- To convert formal prison education provided for prisoners and offenders into extensive system of additional, non-formal and informal education and training

- To integrate educational institutions functioning in educational sphere of a correctional institution and the penitentiary structure to eliminate overlap in the implementation of effective conditions for correction of convicted persons and to prepare the prisoner for success outside of prison and to enhance their social adaptation

- To introduce a multilevel system of vocational training based on partnership with state and nonstate educational institutions of secondary vocational and higher education and cultural and educational centers (Isaev et al., 2013)

- To optimize the content of vocational-andeducational training and make it possible for convicted to acquire appropriate competencies required in the labor market

- To audit and make structured resource base of the educational infrastructure in correctional institutions complementing with opportunities of higher education institutions interacting with them as a regional educational center

- Tocreate the system of methods, techniques and staff support for successful functioning of the educational centers (complexes) (Dorokhov and Khunagov, 2014) in penitentiary system

- To overcome restrictions of prison education only aimed at "correction and rehabilitation", transfer to philosophy of targeting personality development, its self-development and self-actualization in social value system activities

\section{RESULTS AND DISCUSSION}

One of the central issues in the theoreticmethodological studies of education system diversification in a penitentiary institution is development of its model which is based on the ideas of interdisciplinary integration of sociological, psychological and pedagogic knowledge, norms and values which are the components of informative basis for educational system diversification, body of principles of diversification and determinants defining and measuring efficiency of transformations in education (Fig. 1).

The first block includes verified information on the empirical situation in the field of education of persons serving sentences in correctional institutions (prisoners and offenders). In addition to the common challenges every institution has its own characteristic features of the situation for functioning of education system. To do this, it is required first of all to carry out a comprehensive analysis of potential opportunities of educational institutions functioning on the territory of correctional colony with the aim of examining motivation of learning process to obtain a provided level of vocational education, as well as assets and budgets for effective administration and management of changes planned.

The second block includes objectives and tasks. As a strategic goal for diversifying the system of education in the penitentiary field it is advised to determine the search range for effective ways of modernization in accordance with the strategic guidelines for education development in Russia as a whole and sociological-and-cultural transformations in educational environment of the correctional institution in particular (Schepkina, 2012).

Tactical tasks of diversification are the following:

- Scientific justification and reasoning of the process aimed at transforming organizational and functional structure of education system to improve the accessibility and availability of different levels of learning, as well as sustainability and competitiveness of the system through establishing optimal institutional conditions on the basis of cooperative education and prison structures for more effective use of their resources

- Developing and substantiating value-andepistemology theory for reorganization of the prison education institutions and providing education and training in terms of principles representing (in its essence) educational strategies used in pedagogics and teaching and learning practice 


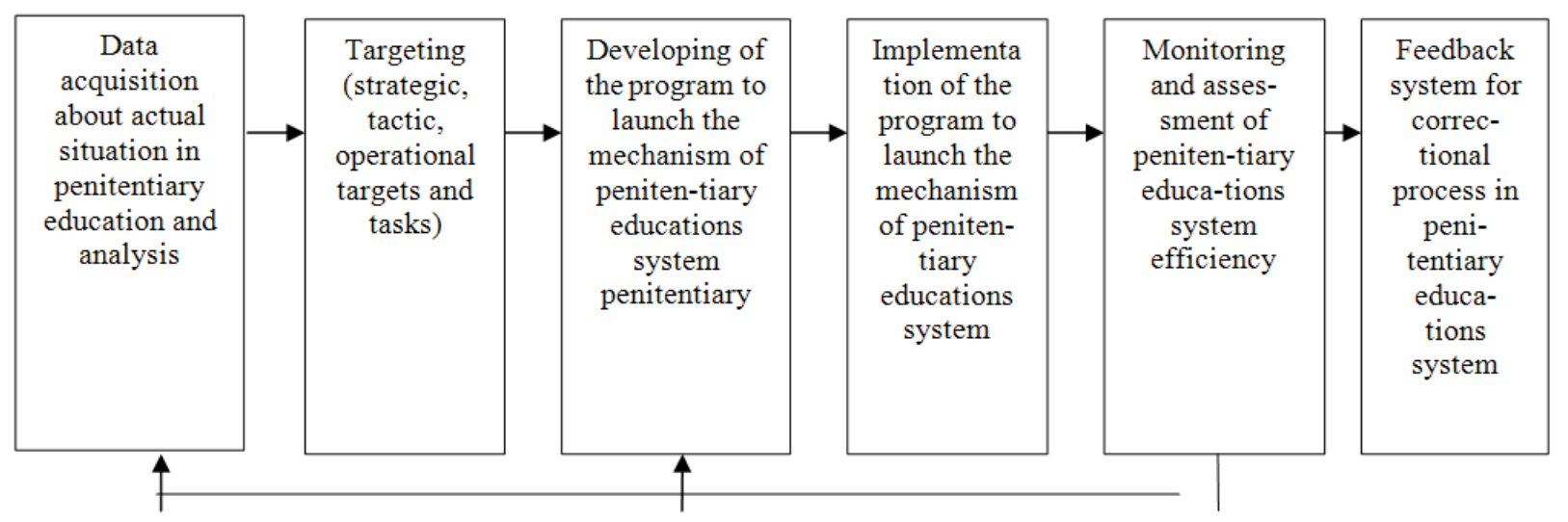

Fig. 1. Process model for prison education system diversification

The above enlisted tasks make it possible to speak about operational tasks of educational system diversifying in penitentiary institutions environment. There objectives here are considered to be the following: To create preconditions for realizing the strategy of sustained education of convicts:

- To change the focus (or refocus) correctional institutions from educating to eliminate gaps in knowledge and skills of convicts (prisoners and offenders) to considering the best interests of employers while provide education and vocational training

- to develop educational facilities integrated in a certain single environment involving funds from different financial sources

- $\quad$ to promote social partnership with aim of attracting highly professional experts to develop methodology, techniques and facilities to ensure penitentiary education system development

The third block the model involves development of diversification program. The first consideration in the design of such program is to identify and describe the main characteristics of educational system and the mechanism for its diversification, as well as the principles which determine the tendencies/orientation and quality to further improve the education system of persons serving sentences in correctional institutions.

The fourth block of the process model of prison education system diversification includes implementation of the program which implies that the task set above is worked out in steps (stepwise). It also suggests creating necessary and sufficient pedagogic conditions to be considered as determinants of its transformation and development.
The fifth block covers the monitoring and assessment of the changes both in educational system and personality of accused or convicted based on their life position, values and attitudes. Qualitative and quantitative assessment of changes in educational system of correctional institutions is carried out on the basis of the criteria of its efficiency:

- Degree of organization and level of the educational system

- Mainstreaming of organizational components functions in educational system

- Stability of the elements involved in the educational structure/system (Volov, 2009)

Accordingly, the sixth block model reflects the established feedback to make corrections in diversification process when applying, for example, inefficient technologies (Schepkina, 2012).

\section{CONCLUSION}

Hence we come to conclusion that education in contemporary penitentiary education system is looked upon as one of the leading means in the process of correcting and rehabilitating of convicts, preparing them for their release and adaptation in the community. It is consolidated by this country legislation that every correction institution should create relevant conditions for obtaining secondary or vocational education by prisoners and offenders. In a number of colonies administrations have established certain conditions for their convicts to receive higher professional education. But this is rather an exception than the rule. However, the occupations list suggested to be studied and trained 
combines the potential of both the educational and correctional institutions located in one environment.

The new system of educating convicts should be based on new and innovative approaches and in no case become a supplement to the normal available education. The basis for it is be laid still at school\% $2 \mathrm{c}$ which is able and must offer about educational amenities and services not only in senior classes but continually during the life. Night shift schools in colonies train and educate adult people with their cognitive needs not limited only to educational objects. All this requires development of additional models, psychological-and-pedagogical conditions to improve basic educational programs of continuing education for convicts (prisoners and offenders), implementation of the mechanism of private sector-and-government partnership in it, improving organizational, economic and management mechanisms while providing education in prisons covering basic applied qualifications and skills.

\section{RECOMMENDATION}

The presented components of the processing model, which belongs to the penitentiary educational diversification system, do not claim to be a complete analysis of the problem and the penitentiary educational system in the whole. It is necessary to outline favorable factors for prisoners and offenders rehabilitation and correction their education and vocational training; to reveal the essence and to show the personalities valuemotivational indications dynamics in the process of education; to determine pedagogical conditions of effective diversification in educational system of colonies for young offenders; to develop recommendations on educational process improving and on prisoners value-oriented activities development.

\section{REFERENCES}

Aungles, A., 1994. The Prison and the Home: A Study of the Relationship Between Domesticity and Penality. 1st Edn., Institute of Criminology, University of Sydney Law School, Sydney, SBN10: 0867589035 , pp: 302.

Bada, B.V., S.K. Balogun and G.A. Adejuwon, 2014. Perceived social stigmatization and coping strategies as predictors of psychological well-being among female partners of prisoners. J. Social Sci., 10: 1525. DOI: $10.3844 /$ jssp.2014.15.25
CFTPE, 2012. Concept of the Federal target program of education for 2011-2015.

Dorokhov, S.M. and R.D. Khunagov, 2014. Social and value foundations of social mobilization capacity of management system in the Russian society. MiddleEast J. Sci. Res., 21: 135-139. DOI: 10.5829/idosi.mejsr.2014.21.01.21311

Fitrianto, A. and Ghazab I.A.B. Maziatul, 2014. Modeling employments rate data using ordinal logistic regression. Middle-East J. Sci. Res., 20: 1715-1720.

DOI: 10.5829/idosi.mejsr.2014.20.12.21085

Isaev, A.V., L.A. Isaeva and A.G. Kravets, 2013. Individualized educational trajectory: Educational courses integration submitted. World Appl. Sci. J., 24: 62-67. DOI: 10.5829/idosi.wasj.2013.24.itmies.80013

Masalimova, A.R., 2013. Corporate Training the Mentors. 1st Edn., Printing Service-XXI Century Press, pp: 183.

Mukhametzyanova, G.V., 2010. Priorities of vocational education in the modern theory and practice. Secondary Vocat. Educ., 10: 2-7.

Poznyshev, S.V., 1923. Basis of the Penitentiary Science. 1st Edn., Minkompros Press, pp: 342.

Schepkina, N.K., 2013. Theoretical bases of diversification of penitentiary educational system. Acad. J., 6: 179-203.

Schepkina, N.K., 2012. Theoretical and methodological foundations of penitentiary education diversification. MSc., Thesis, Institute of Pedagogy and Psychology of Professional Education of the Russian Academy of Education, Kazan, MI.

Shaydullina, A.R., 2009. Principles of integration "ssuzuniversity-production" in terms of continuing professional education. Higher Educ. Russia, 5: 140144.

Volov, V.T., 2009. Higher Education as a Factor of Management Socialization of Convicts in Prisons. 1st Edn., Samara State University Press, pp: 392. 